How to Cite

Shiukashvili, T. (2019). Folk tales as genre in Georgian and English folklore. International Journal of Social Sciences, 2(1), $33-$

37. https://doi.org/10.31295/ijss.v2n1.66

\title{
Folk Tales as Genre in Georgian and English Folklore
}

\author{
Tamar Shiukashvili \\ Telavi State University, Georgia \\ Email: tamar.shiukashvili@gmail.com
}

\begin{abstract}
The article deals with the most popular and significant genre of Georgian and English folklore - a folk tale. It reviews first of all the definition of folk tales, structure of Georgian and English folk tales as a genre of folklore. It discusses the anthropomorphic figures as a symbol of evil and kindness. The aim of our research is to consider the peculiarities of the Georgian and English folk tales, show differences of these folk tales through comparison.

Keywords---Georgian and English folklore, genre, anthropomorphic figures, structure, folk tales.
\end{abstract}

\section{Introduction}

Folk tale are the tales of the folk, i.e. me, you, we and they. They are tales about the wise and the foolish, the rich and the poor, men and women, the old and the young, the brave and the cowardly. They are often humorous involving trickery or foolishness. They can also be serious tales of heartbreak and romance. They include Urban Legends - the most popular living oral tradition - humorous or grim tales that play upon the neuroses of life in the developed world http://www.crickcrackclub.com/MAIN/TYPES.PDF.

Folk tales are the most ancient creations of humanity. A folk tale is one of the popular and favorite genres in folklore and in literature. It is well known that wisdom and spirit of the people, of the nation are shown in the traditions, especially in folklore, and the knowledge of folk tales promotes not only to know a language at best, but also facilitates best understanding of views and characters of the people (Sikharulidze, 2012).

Folk art is various and interesting phenomenon. He still records positive contribution to the development of humanity. The main formation of the genius of the people is a fairy tale, which has the largest part in formation of people's outlook, despite the seeming simplicity and linearit (Nateladze, 2012).

Fairy folk wisdom is one of the oldest and popular genre. It was created orally by our ancestors a long time ago. Orally because, that at this time when these tales were created, they did not know writing of the letters. By then people memorized these orally stories by listening and conveyed to posterity by heart again. During the many hundreds of years, these verbal fantastic stories have moved around the corners and from generation to generation. The destination of the tale was especially great as long as the script developed by the people. But neither writing nor the book did not destroy tale. It was developing and spreading alongside the writers, because it had its own function and tradition [http://elasevenia.blogspot.com/2012/12/blog-post_6874.html].

As it's known, the folklore tale is seen as related to the elements of the internal unity of the system caused by the formation of ideological and psychological content, motives, stories, genre composition and artistic styles of the signs (Gogiashvili, 2013).

World fairy tales have lots of things in common according to the ideological and thematic substance, the hero's character, the story, composition, and with origin and ending. Andersen told the story like everywhere confined within certain limits - it is specifically thought out and provided that the main focus is transferred on right and wrong, good and evil, however, national color, its originality in all the people's tale is clearly separated (Nateladze, 2012).

A fairy-tale is the most diverse among the genres of oral literature, so it became necessary to demarcate the compositions of this kind and distinguish its sub-genres. These are: magic fairy-tale, animal fairy-tales and everydayrealistic fairy-tales. Scientific research has revealed that fairy-tale eposes of the world people are based on

ISSN 2632-9409

Received Jan 18, 2019 / Accepted Jun 18, 2019 / Published Jul 05, 2019 
homogenous units - motives and despite the external diversity of these stories, their basic material is homogenous. This led to formation of catalogues of fairy-tale motives, which are successfully used by folklorists (Aarne \& Thompson, 1961).

There are many different definitions of folk tales. As Chikovani mentioned it is Oral fantastic story tale. Its plot is typical for fantastic items that are included in this genre (Chikovani, 1946).

Origin of the fairy-tale, its history is lost in the depth of the past like the history of other genres of oral literature. Folklore (meaning "people's wisdom") had been orally created during centuries and orally transferred from generation to generation. Therefore, we do not have a trustworthy document of when, how, and under what conditions this or that genre originated, what way of formation it went through until it reached us in the given form (Kurdovanidze, 2002).

Folk tale has a long history as in oral as in writing. Orally as a genre it is being society of classless. Also the history of written tale isn't long. One of the ancient fantastic fiction was written an old Egyptian language. The most famous ancient fairy-tale about two brothers was fixed in papyrus in three thousand years ago. Similar motives and plot can still be found in folklore (Chikovani, 1946).

The Georgian writer and lexicographer Sulkhan-Saba Orbeliani (1658-1725) defines the term zghapari as a fictitious lie, handed down in the form of a story. The other Georgian terms for the oral prose genres are ambavi and araki, meaning "a story". The negative connotations of zghapari through the Middle Ages stems from theological differences between Christianity and paganism (Gogiashvili, 2013; Citrawati et al., 2016; Aini, 2017)).

What is folk tale? Folk tales are the most ancient creations of humanity. A folk tale is one of the popular and favorite genres in folklore and in literature. A fairy tale is a wonder tale involving marvelous elements and occurrences, though not necessarily about fairies. Folktales have received literary treatment from early times http://yun.moluch.ru/archive/6/360

Folktales are those orally transmitted stories that are understood as fictitious; they function mainly as entertainment but also convey values. Myths and legends, on the other hand, are belief tales, regarded as true accounts of past events; they can be entertaining but principally serve to support the belief system and as folk history http://www.georgiaencyclopedia.org/articles/arts-culture/storytelling-traditions

Some old written sources mention Georgian folk tales, including translations of the Bible from $5^{\text {th }}-7^{\text {th }}$ centuries and the original Georgian hagiographie and secular literature of the Middle Ages. The term "Zghapari" the Georgian word for fairytale, translates "lie" and "fictitious story". "It was but it was nothing" - so reads the traditional beginning of Georgian fairytales. Zghapari connoting a "fictitious story" is used in Georgian hagiographic literature with the negative meaning in contrast to the factual report (Gogiashvili, 2013).

According to the classification of modern Georgian oral folklore by professor Chikovani contain various genres covering 1. Animal tales, 2. Magic tales, 3. Novelistic - realistic tales, 4. Legends, 5. Anecdotes, 6. Herotic epos http://elasevenia.blogspot.com/2012/12/blog-post_6874.html

The Georgian folktales feature numerous cases where the plot of the fairytale is based upon myth but the myth has not been transformed into a fairytale. The majority of these examples comes from the mountain regions of Georgia, suggesting that mythical thought was more prevalent in these regions than in the plains (Gogiashvili, 2013).

One of the peculiarities of the English and Georgian folk tale as a genre is that it is intended not only for children but for adults. Such kind of Georgian folk tales are: Natsarqeqia, Aspurtsela, Conkiajgharuna, Gulambara and Sulambara, Ghvthisavari (I am of God) and etc. in English they are: tom tit tot, The Three Sillies, Jack and the Beanstalk, Nix Nought Nothing, Cinderella, snow white, Little Red Riding Hood; Princess Furball; Why Mosquitos Buzz in People's Ear; How Many Spots Does a Leopard Have? And so on. The world of a magic folk tales of Georgian and English folklore is an unreal world.

Comparing English and Georgian folk tales can make it clear that they contain much in common. All English and Georgian folk tales begin this way. For example:

Traditional formula at the beginning of narration in English folktales is „Once upon a time there was... And in

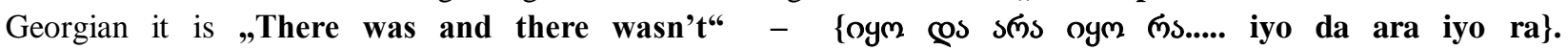

These beginning phrases clearly points to the fact that the narrated story is taken beyond the time and space in both folk tales of Georgian and English languages. It should be noted that the Georgian and English folk tales show the national originality of folklore. Besides that they are the first publisher of peculiar rhythm and tone, they create the mood for English and Georgian readers.

About an opening phrase like "Once upon the time and place" of folktales Aarne A, Thompson mentioned in his book which is about "The types of the folktales" that it may be considered cumbersome and even perhaps regarded as unnecessary ("Long, long ago and beyond the beyond" may be an acceptable alternative) (Aarne \& Thompson, 1961). 
As for the end of the phrase, it differs the Georgian and English languages. Georgian folk tale ending can be found diverse and more traditional forms. Several types of endings are represented. However, it is known that the Georgian folk tale has fantastic, abstract, and other typical blessed endings. The most popular form of Georgian folk

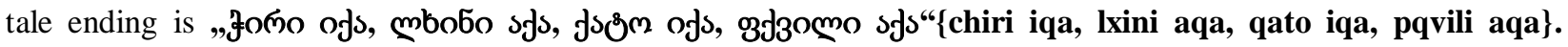
Georgian folk tales characterized to start and finish text - according to the stereotype blick. „Plague there, fest

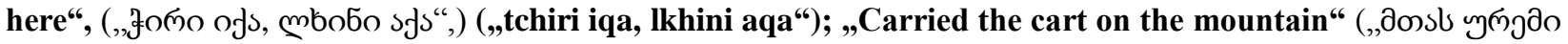

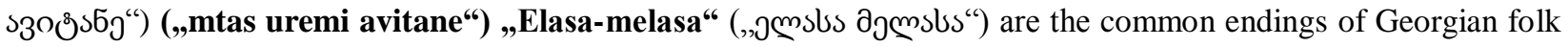
takes.

Different from the Georgian language the ending of English folk tales carries a non-figurative character. For example: „And the king married his daughter to the young man that had delivered her, and gave a noble's daughter to his brother; and so they all lived happily all the rest of their days" The Red Ettin http://www.surlalunefairytales.com

As for the plot of Georgian and English folklore there are many names between two different languages of folk

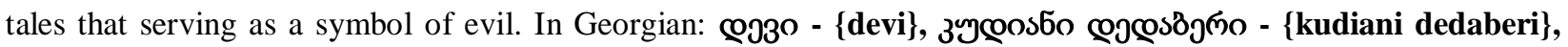

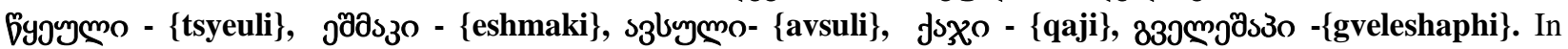
English: The difference is minor between the languages. In English folk tales Giant and Dragon have corresponding meaning as symbols of evil. It has been revealed that all magical folk tales reflect in the relation of contradiction where kindness always wins. Symbols of kindness in the Georgian folk tales are: foofsms - \{tsiqara\}, ozslzyø6zo \{paskunji\}, ґऽðоo - \{rashi\}. In english are: Fairy, Steed, Swans, Griffin of the Greenwood.

Many Georgian fairytales feature a supernatural being with an ambivalent character: the gveleshapi ("snakewhale") which represented dragon. In general, the word dragon in the folklore of the peoples of Europe (as well as its variants such as German Drache, English dragon) are derived from the Latin word draco, which means 'snake (Gogiashvili, 2013).

One of the important supernatural beings in Georgian folk tales is the giant called devi, a representative of the principle of evil, but with certain limitations, neither incorporeal nor immortal, but half demon half man, i.e. an unclean spirit in the form of a giant. He is subject to death even a man can kill, cheat and terrify him; he can marry a woman. His nature is also ambivalent like the snake: sometimes he is an enemy but sometimes a friend of the hero (Gogiashvili, 2013).

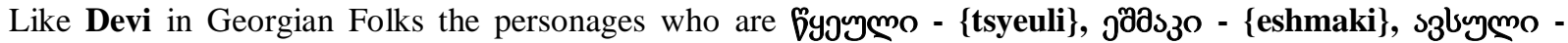
\{avsuli\}, Jsxo - \{qaji\} they all serve the evil in folk tales.

According to the dictionary of etymology there is such definitions of Giant: "fabulous man-like creature of enormous size", from old French geant, earlier jaiant "giant, ogre" http://www.etymonline.com/index.php?term=giant. In English folk tales the Giant is a symbol of evil and also he is a man who can kill enormous people in folks.

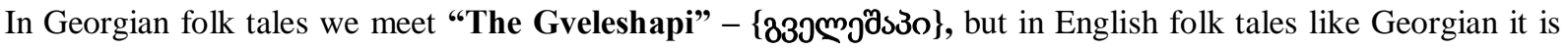
"Dragon". They both can either be an enemy of the hero or a friend.

There are various kinds of witches in Georgian folk tales. One of them is devis deda "the mother of the devi". She is dangerous but if the hero speaks politely and respectfully to her, she will help him. Further witches are ali the beautiful women with golden hairs living in water, in forest or in huge rock caves, rokapi - the ugly woman with demonical character, and dedaberi - the old wise woman. All of them have an ambivalent nature. Whether they show their positive or negative power depends on the hero's behavior (Gogiashvili, 2013).

In English folk tales we also meet the face of withches. Like Georgian folk tales she is an independent personages of English folk tales who is dangerous, magician and sorceress. She is a woman supposed to have dealings with the devil or evil spirits and to be able by their cooperation to perform supernatural acts.

The most common helpful animals and birds in Georgian and English folk tales are the horse, the bullock, the ram (sheep), Steed, Swans, Griffin of the Greenwood. Many Georgian and English folktales feature a supernatural being with an ambivalent character.

The motif of the grateful animals is one of the most popular motifs in the magic tales: A hero earns the thanks of several animals "deer, fish, bird, snake etc.) and with their help solves all difficulties in his life. There are some fairy tales in the Georgian folklore which present the animals not just as grateful minor characters of the plot but as trustworthy friends of the hero. In the genres of the Georgian folklore, different relationships between a human being and the environment are presented. The mythic hero respects the natural world because he is afraid of it. Conversely the fairy tale hero feels responsible for the natural world and loves it because he regards it as similar and equal friend (Gogiashvili, 2011). 
In many Georgian and English folk tales the hero usually goes down into the underworld, rescues the king's daughter from the captivity of the Snake, Gveleshapi or Dragon and returns to earth. In English folk tales there has always known the name of hero and he is Jack. As for Georgian hero hasn't known as a name. In Georgian folk tales

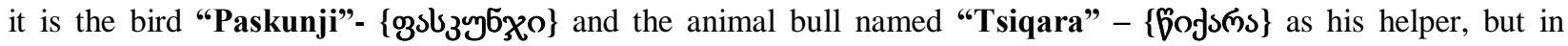
English folk tales they are the Griffin of the Greenwood and Swans. They are always the symbol of kindness.

A paskunji (Lat. Neophron percnopterus, Eng. Egyptian vulture, common also in Georgia) is a very important character in Georgian folk tales. In Georgian fairytales Paskunji belongs to the range of fantastic creatures (Gogiashvili, 2013).

The Paskunji and the Gveleshapi represent the couple that will necessarily be present in tales of the hero's adventures in the underworld. In Georgian folk tales the meeting point of the opposing gveleshapi and paskunji is the tree where the paskunji has a nest. This motif preserves the oldest myths of the cosmic tree (the World Tree, Iggdrassil). According to the Georgian mythological tradition, the centre of the Universe is occupied by a poplar tree emitting myrrh, and in ancient Georgian ornaments the motif of the World Tree is abundant (Gogiashvili, 2013).

In Georgian and English folk tales the animals and birds possessed ambivalent qualities in folklore, where the bird dwells in the lower world, and the animals can move on the ground, they can also fly. In Georgian folk tales the gveleshapi, defeated by the hero, has no wings, but in English folk tales the dragon can fly and has always wings. As for animals especially "horse" which is known as "rashi" in Georgian folk tales and "steed" in English, both of them have miraculous qualities they can fly from one place to another.

\section{Conclusion}

Anthropomorphic figures are very interesting both of two different kinds of folklore. The universe of the Georgian and English folk tales are the time. Everybody is equal here. It is the universe which cannot exist on the earth. Time does not move and the characters' age does not change. In Georgian and English folklore have many characteristics common to the beginning structure of the folk tales.

From the perspective of artistic chronotope and its linguistic units' expression, the intial and final formulae of Georgian and English folk tales are close to both folk tales and the inner opposition of its real world. Despite the system of the different languages the initial formulae of folk tales are related to the name of one specific essential formula (animate and inanimate). The rhythm and figurative ending is characterized for Georgian folk tales. The ending of English folk tales is non-figurative.

Georgian and English Folk tales are the artistic chronicle of fight against the evil. It has been proved that all magical Georgian and English folk tales reflect to the relation of contradiction where kindness always wins.

We came to a conclusion that Georgian and English folk tales have similarities and differences

\begin{tabular}{|c|c|c|}
\hline Folk tales elements & English folk tales & Georgian folk tales \\
\hline $\begin{array}{l}\text { Special beginning and/or } \\
\text { ending words }\end{array}$ & $\begin{array}{l}\text { Once upon a time ... and they lived } \\
\text { happily ever after. }\end{array}$ & 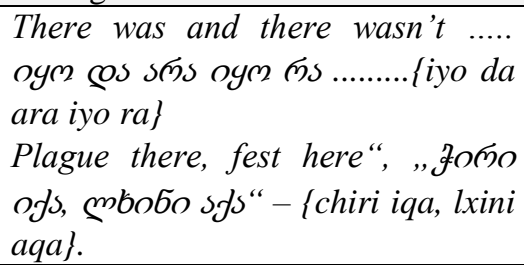 \\
\hline Good characters & $\begin{array}{l}\text { Steed, Swans, Griffin of the } \\
\text { Greenwood. }\end{array}$ & 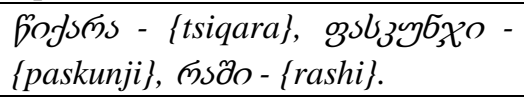 \\
\hline Evil characters & Dragon, witches & 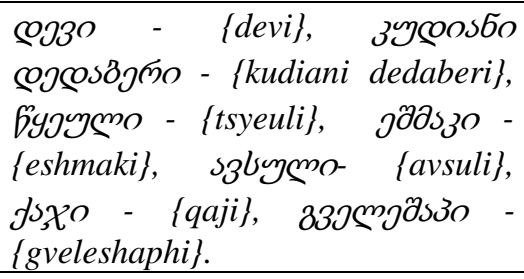 \\
\hline Time & $\begin{array}{l}\text { The tale doesn't indicate an exact } \\
\text { timeline of occurrences }\end{array}$ & $\begin{array}{l}\text { Doesn't indicate an exact timeline } \\
\text { of occurrences }\end{array}$ \\
\hline Place & $\begin{array}{l}\text { The tale doesn't indicate any } \\
\text { specific location of occurrences. If }\end{array}$ & $\begin{array}{l}\text { The tale doesn't indicate any } \\
\text { specific location of occurrences. If }\end{array}$ \\
\hline
\end{tabular}




\begin{tabular}{|l|l|l|}
\hline & it does the location is fictional & it does the location is fictional \\
\hline Plot structure of folk tales & $\begin{array}{l}\text { Realistic plot. Everything was taken } \\
\text { from real everyday life }\end{array}$ & $\begin{array}{l}\text { Realistic plot. Everything is } \\
\text { described rather realistically }\end{array}$
\end{tabular}

\section{References}

Aarne, A. (1961). The types of the folktale: A classification and bibliography. Suomalainen tiedeakatemia.

Aini, Z. (2017). The actualization of cultural elements in novel Guru Onyeh by Salman Faris. International Journal of Social Sciences and Humanities, 1(3), 17-27. https://doi.org/10.29332/ijssh.v1n3.49

Chikovani, M. (1946). Georgian folklore, publisher the newspaper „Ленинское знамя“.

Gogiashvili, E. (2011). The Dynamic of mythical and Religious Symbolism in the Structure of Magic Tale. Tbilisi: Universal.

Gogiashvili, E. (2013). About Georgian Fairytales. BABELAO, 2, 159-171.

Kurdovanidze, T., \& Kurdovanidze, T. (2002). Georgian Folktale.

Nateladze, N (2012). About the Translation of the Opening and the End of the Georgian Folk Tale, In Modern And Contemporary History 1 (11) Studies, Tbilisi.

Sikharulidze, K. (2012). Fairy-Tale as a Genre. Journal of Education, 1(2), 91-94.Citrawati, P. E. W., Wahyu, G. E., \& Aryani, I. G. A. I. (2016). Moral values in folklore of Pan Balang Tamak story (sociolinguistic study). International Research Journal of Management, IT and Social Sciences, 3(5), 89-93.

http://www.crickcrackclub.com/MAIN/TYPES.PDF

http://www.etymonline.com/index.php?term=giant

http://www.georgiaencyclopedia.org/articles/arts-culture/storytelling-traditions

http://www.surlalunefairytales.com

http://elasevenia.blogspot.com/2012/12/blog-post_6874.html

http://yun.moluch.ru/archive/6/360 